\title{
Study Of Critical Disadvantages System Catur Varna To Concept Catur Kasta In Civil Society Bali Hindu
}

\author{
I Made Purana \\ Faculty of Training and Pedagogy Dwijendra University, Indonesia \\ madepurana11@gmail.com
}

\begin{abstract}
The people apanage of Bali know the concept of Kasta. Such stratification creates different views between the Tri Wangsa and jaba groups. The Tri Wangsa want an acribed status, whereas the Sudra or Jaba group want the achieved status, which in turn leads to polemics among the people of Bali apanage. As a qualitative study with a cultural perspective, this study aims to reveal and analyze more clearly the blurring of the varna system into a kasta concept in Balinese Hindu society. Data sources are extracted based on bibliographic or documentary data. Data collection using reading techniques and recording techniques. Data analysis on the problem is done by qualitative descriptive analysis and comparative analysis. The results showed that the blurring of the varna system into a kasta concept is inseparable from the royal politics of its time. The traditional educational system originating from Hindu literature and religion can only be enjoyed by the upper layers, the brahmins and the knights, while the sudra or jaba classes are strictly prohibited. The Kasta architects of Bali in the past few centuries, so expertly exploit the situation of the backwardness of Hindus outside the brahmans and the knights, so the teachings of Hinduism are manipulated in terms of caste naming. The elements of caste plagiarize the elements of varna that are indeed Hindu teachings. In addition, Dutch colonial politics is also very influential on the order of life in Bali, which causes problems in the system of social status. The Dutch government has not fully implemented the modern system of government. This is evident in the system of appointment of new employees (civil servants). The Dutch government has not carried out according to rational legal criteria, but still uses the traditional system of judging a person in terms of the height of the Kasta, not in terms of ability. Therefore, it is necessary to increase knowledge of village manners in the field of customary law and knowledge of village manners in the field of religion according to what is stated in the Hindu scriptures.
\end{abstract}

Keywords: Critical Discourse; Vagueness; Catur Varna; Catur Kasta

\begin{abstract}
Abstrak
Masyarakat Bali apanage mengenal konsep kasta. Stratifikasi semacam itu menimbulkan perbedaan pandangan antara golongan tri wangsa dengan golongan jaba. Golongan tri wangsa menginginkan acribed status, sedangkan golongan sudra atau jaba menginginkan achieved status, yang pada akhirnya menimbulkan polemik di kalangan masyarakat Bali apanage. Sebagai kajian kualitatif yang berpradigma budaya, penelitian ini bertujuan untuk mengungkap dan menganalisis lebih jelas terjadinya kekaburan sistem warna menjadi konsep kasta dalam masyarakat Bali yang beragama Hindu. Sumber data digali berdasarkan data kepustakaan atau dokumenter. Pengumpulan data menggunakan teknik pembacaan dan teknik pencatatan. Analisis data terhadap permasalahan dilakukan analisis deskriptif kualitatif dan analisis komparatif. Hasil penelitian menunjukkan bahwa terjadinya kekaburan sistem warna menjadi konsep kasta tidak terlepas dari politik kerajaan pada zamannya. Sistem pendidikan tradisional yang bersumber pada kesusastraan
\end{abstract}


dan agama Hindu hanya boleh dinikmati oleh lapisan atas, yaitu golongan brahmana dan golongan ksatria, sedangkan golongan sudra atau jaba dilarang keras. Arsitek kasta di Bali pada beberapa abad lampau, begitu ahli memanfaatkan situasi keterbelakangan umat Hindu di luar kaum brahmana dan kaum ksatria, sehingga ajaran agama Hindu dimanipulasikan istilah-istilahnya untuk pemberian nama kasta. Unsur-unsur kasta menjiplak mentah-mentah dari unsur-unsur warna yang memang merupakan ajaran Hindu. Di samping itu, politik kolonial Belanda juga sangat berpengaruh terhadap tatanan kehidupan di Bali, yang menimbulkan permasalahan dalam sistem status sosial. Pemerintah Belanda belum menerapkan secara sepenuhnya sistem pemerintahan yang modern. Hal ini tampak dalam sistem pengangkatan pegawai baru (pegawai negeri). Pemerintah Belanda belum melaksanakan menurut kriteria legal rasional, tetapi masih mempergunakan sistem tradisional, yaitu menilai seseorang dilihat dari segi tinggi rendahnya kasta, bukan dilihat dari segi kemampuan. Oleh karena itu, perlu adanya peningkatan pengetahuan krama desa di bidang hukum adat dan pengetahuan krama desa di bidang agama sesuai dengan yang tercantum di dalam kitab suci Hindu.

\section{Kata Kunci : Wacana Kritis; Kekaburan; Catur Warna; Catur Kasta}

\section{Introduction}

Discourse analysis is intended as an analysis to dismantle certain intents and meanings (Swarniti, 2019). While discourse is an effort to reveal the hidden meaning of the subject, which expresses a statement (Eriyanto, 2001). The disclosure is done by placing itself in the speaker's position with the interpretation following the meaning structure of the speaker.

Discourse analysis is not centered on the truth/unrighteousness of grammatical structures or interpretation processes as in constructivism analysis (Swarniti, 2021c). Discourse analysis in this paradigm emphasizes the constellation of forces that occur in the production process and the reproduction of meaning (Swarniti, 2021b). Individuals are not regarded as neutral subjects who can interpret freely according to their minds because they are deeply connected and influenced by the social forces present in society.

The language in critical view is understood as a representation, which plays a role in shaping certain subjects, themes of particular discourse or strategies within them. Therefore, discourse analysis is used to dismantle the power, which exists in every process of language, what limitations are allowed to be discourse, perspectives to be used, what topics are discussed (Swarniti, 2021a). With this view, the discourse of seeing language is always involved in power relations, especially in the formation of subjects and the various representational acts contained within society.

The life of modern society has brought about a change in the field of intensive industrialization (Santika et al., 2021). This era is a challenge of Hindu religion in maintaining srada society because in modern society there has been a shift of view of life from irrational to rational, from tolerance to individual. Departing from the advanced level of public education and the opening of inter-ethnic and intercultural associations has impacted on changes in attitudes and views of society (Sutrisno et al., 2019). "Hindu society demands an individualized religious adherence to dharma because the situation of the modern world carries much stress on the inner life of man, which affects the frustrations and rigors of life that are so strict, it requires adequate religious / dharma guidance as a controller" (Bagus 1991) And criticize the teachings of Hinduism to suit the demands of the times.

The traditional education system that is based on Hindu literature and religion can only be enjoyed by the upper layers, namely brahmins and knights. Because of the bigotry 
and the social structure of life that is always bound by the norms of religion and caste, the openness of receiving a democratic view is limited to the jaba, the lowest caste (Santika, 2021). After the 1900s, then the Western educational system in Bali began to grow so that ideas arise in the community renewal like the desire of equal rights between the group of tri wangsa with jaba group.

The influence of Dutch colonial politics in improving the order of life in Bali, causing problems in the system of social status. The Dutch government's attempts to make changes in the system of government have not fully implemented a modern system of government. This is evident in the system of appointment of new employees (civil servants) (Santika, 2020). The Dutch East Indies government has not implemented according to rational legal criteria but still uses the traditional system, which is judging a person in terms of the high and low caste. This status difference creates social conflicts in society, especially by the people of North Bali. It was this situation that eventually led to the demands of some of jaba's group, who had been educated, so that the tri-part of the community would respect each other and respect each other in the social life according to the demands of the times (Santika et al., 2019).

This study aims to reveal and analyze more clearly the blurring of the varna system into the concept of caste in the Hindu Balinese society. Theoretically, this research is useful to add to the repertoire of knowledge in the socio-cultural field related to the blurring of the varna system into the concept of caste in Balinese Hindu society. Empirically, this research is expected to provide input and can be used as material for consideration, especially for Hindus and for related Hindu institutions, for fostering customs and culture in Balinese society. The theory used to dissect the problem is the intertext theory of Yulia Kristeva in Kuta Ratna (2005: 602), the theory of social practice from Pierre Bourdieu (Bagus Takwin, tt: xvii-xviii), and the theory of deconstruction by Jacques Derrida (Barker, 2004: 76-80 ).

\section{Method}

This type of research is a type of library research. This research is viewed from the perspective of cultural studies with an interdisciplinary approach. Sources of data obtained from the study of documents. The research instrument is the researcher as the main informant because he acts as an observer when reading the object of research and taking notes on a regular basis. Data collection techniques used includes reading techniques and recording techniques for the problems studied. This technique is applied through three stages, namely orientation/description, reduction/focus stage, and selection stage. Data were analyzed descriptively qualitatively with induction and argumentation techniques.

This research is expected to provide a stimulus for academics to examine more critically, conduct further, in-depth, and intensive research on the social impacts that arise as a result of the blurring of the varna system into the concept of catur kasta in Balinese Hindu society.

\section{Result and Discussion}

Why are there still differences in human dignity and status in Hindu society? Why do these questions always come up? Why do so many non-Hindu people mention that in Bali there is a kasta? One reason is that Hindus are less vocal explaining this issue, lack of reference, whether in the form of books or scientific publications circulating widely explaining the problem of kasta pengajegan this.

The elements of kasta plagiarize from the elements of varna, which are indeed Hindu teachings. This is the base. The caste architects of India and Bali in the past 
few centuries, so expertly exploit the situation of the backwardness of Hindus so that Hinduism is manifested in terms of caste-naming (Putu Satia in Wiana, 1992).

Catur Varna is the cornerstone of Hindu community conception based on Hindu scriptures. The word Varna (originally varna) is derived from the Sanskrit language of veins vri means choosing employment. Catarur Varna divides the Hindu community into four groups of professions in horizontal parallel. The varna is determined by the guna and karma. Guna is the nature, talent and nature of a person, while karma means deed or work. Guna and karma is what determines the varna of a person.

The formulation of the varna system problem is clearly stated in Bhagavadgita IV, 13, namely:

caturvarnyam maya Srstam

gunakarmavibhagasah

tasya kartaram api mam

viddhy akartaram avyayam

Meaning:

Catur Varna I created according to the division of use and karma (nature and work). Though I am as its creator, know Me overcome motion and change (Mantra, 1967).

The definition of Varna according to nature and function is divided into four based on obligations. People can serve as big as possible according to their nature. He can perform his duties with a sense of love and sincerity in accordance with the teachings of Hinduism.

In Bhagavadgita XVIII, 41, it is stated that brahmins, knights, waisya, and sudra. The four classes are based on swabawa and use not by the people. The sloka text is:

brahmana ksatria visam

sudranam ca parantapa

svabhava prabhavair gunaih

Meaning:

$\mathrm{O}$, Arjuna, tasks are divided according to nature, the nature of his birth as well as brahmans, ksatria, waisya, and also sudra (Mantra, 1967).

The division of this class is actually not found in Hinduism but, its nature is universal. Classification depends on the nature of man from his birth talent. Each of these four classes has a certain character. It is not always determined by heredity. In the Bhagavadgita, varna theory is very broad and deep. Every being has its birth character (swabawa) and which makes it effective in life is its obligation (swadharma).

The wangsas of Indonesians in Bali was reinforced by customary law, which gave privileges to the higher ranks. Given these privileges that look down, the stronger the public wangsa that they are the same as kasta (Kertih dan Susila, 2014).

The occurrence of development in society Button varna system that is obscured or mixed with the kasta system because the public in general to see the bitter realities experienced by Hindus in social history. This chances are most likely due to the terms in catur varna almost the same as in kasta terms (Darsana dan Holilulloh, 2015).

The problem is the blurring of the wangsa or kasta with the Catur Varna teachings in Hinduism. This is due to the low educational factors and the lack of dissemination of Veda books. As a result, the clergy who are indeed brahmanas in accordance with the concept of Catur Varna, until the offspring were also called brahmana, whereas the offspring are not clerics. Likewise, the royal authorities and the government and their families are called ksatria. However, if traced more deeply, especially the so-called sudra / jaba, most of the sudra/ jaba group has an ancestor of knights and brahmins. This is in accordance with the opinion of Wiana and R. Santeri (1993) that "vaguely in Bali there is also the term waisya and sudra. Both terms are highly likely to mimic the term waisya and 
sudra in a kaste system in India. Some people who happen to be "in power" often refer to sudra if the person is from jaba, when the genealogy of the person called jaba wangsa has a ksatria or brahmana ".

This is in accordance with his opinion Kerepun (2004) that because of the policy of the pre-colonial kings, there are some soroh or class of Balinese, members of his family still use the title of nobility, some do not use the title of nobility. For example in Prati Sentana Sri Nararya Kepakisan, Prati Sentana Arya Kanuruhan, Arya Penatih, Arya Pengalasan, and others, some are using the title of nobility, some are not. In the case of religion (because it does exist not because of Hinduism) all three are the same. All three groups can mediksa (spiritual learning) to become a pastor. After the independence of Indonesia and the feudal kingdom system was abolished, many of the so-called jaba wangsa studied high and also studied religion correctly. The clergy of this class also held a sacred ceremony or became dwijati (pendeta). This development took place after the Campuan Ubud Competition in 1961, a large gathering of Hindu figures. However, on "certain people", the traces of the differences are still there.

Humans in practicing religious teachings have many different limitations and abilities. There are people who practice the teachings of that religion with full understanding, but there are also people who practice the teachings of that religion with a very limited understanding. Religious teachings that are practiced by people with limitations that often lead to religious traditions that are not in accordance with the teachings of Hinduism. Moreover, the wrong tradition that lasts for centuries, of course, requires sufficient perseverance and time to return to its true teachings.

The Hindu assembly, Parisada Hindu Dharma Indonesia (PHDI), was the pioneer in clearing up caste misunderstandings in Hinduism. Since the 1960s, PHDI has published a religious handbook for school children, named Upadesa. In the book it is stated clearly that there is no difference in human dignity and status among Hindus (Setia, 1993: ix).

The vertical social stratification of society, such as caste, does not exist in Hinduism. "There is absolutely no caste division within the Hindu religion. The term caste that has been known to the public, such as brahmana, knight, vaisya, and sudra is the color or function of each member of the community. Anyone can enter the category of brahmin, knight, vaisya, and sudra" (Wiana and R. Santeri, 1993: 74).

In fact, until now there are still Hindu religious activities that are carried out very far from the concept. There is a controversy between the philosophy and its concepts, which are contained in the holy book, and the daily practice of Hindu religious life. Hindu idealism and Hindu realism in individual and daily social life are still far different and even contradictory. This means that there are still Hindu cultural behaviors in Bali that are carried out contrary to Hindu teachings, which are stipulated in the Hindu scriptures. One of the Hindu cultural systems, especially in plain Bali, which is contradictory is the religious system, especially concerning the teachings of catur varna.

The sacred teachings spoken by God are no longer in accordance with their practice in society. It has been going on for centuries. The discrepancy is that the color chess teaching has shifted to the catur wangsa teaching (tri wangsa and sudra) into the caste concept even though the catur varna system and the caste concept are very different. The catur varna teaching classifies humans based on profession, while the caste concept distinguishes human dignity based on descent. That is, there are descendants that are higher and there are those who are lower. This has made the image of Hinduism very tarnished. Hindu culture carried out by Hindus is not in accordance with even against the system of Hindu religious teachings. Considering that the ideas in the difference of opinion are still actual today and occur in various societies, it is very possible to state that the tension between tradition and modernization is a universal discourse. 
The reinterpretation of old values continues to occur in plain Bali and is colored by a tug-of-war between reinforcing and reinforcing the dominant discourse on tradition or updating it with something radical. For example, was the feudal society with the concept of caste or dynasty maintained or reformed with an egalitarian society? Reference values and interests of diverse and contradictory groups make the Balinese people feel like they are at a crossroads. Time will tell in which direction the group will go or be carried away, although there are many criss-crossing analyzes of this phenomenon (Dharma Putra, 2004: xi-xii).

Departing from the advancement of the level of public education and the opening of relationships between levels of public education and the opening of inter-ethnic and international relations, this has resulted in changes in people's attitudes and views of life. The openness of Hindu culture into the scope of modern civilization has developed a broad insight into humanity. Along with that, there has been a shift in human values that oppose the continuation of the identity of the nation's personality. The illustration provides a reflection that change will continue in human life which is determined by two pull forces, namely good and bad which are eternal. This illustrates the dualism in Hinduism known as rwa bhineda will continue to exist and continue.

Agung (1974: 6) states that in the traditional society of plain Bali, the issue of social status is determined by the caste system. Each of these caste groups seems to have determined its status according to its identity (birth of offspring) and its dharma (jobs). The Brahmin caste group served in the religious field, the knight class served in the field of government, the Vaisya class in agriculture and trade, the Sudra (jaba) group served to help the three groups. But in reality what was happening in the plains Balinese society at that time, such a division of tasks was not fully implemented.

The classification based on the caste concept gave rise to a multi-level social structure that gave rise to differences in rights and obligations between the tri wangsa group and the jaba group. Such differences by the Dutch colonial government were sharpened again by maintaining customs and maintaining traditional government structures. Even though some of these groups are classified as modern elites, these groups still have a traditional view and still maintain the ascription criteria, namely the status of work obtained based on traditionally accepted descent (Agung, 1974: 7).

In general, every social change is always accompanied by a process of change or social mobility that brings clashes of values that result in disharmonious relationships. culture, and religion are the main elements in the formation of Balinese cultural identity, but when Balinese people come to the discourse of identity and modernity, problems always arise regarding which customs and traditions must be preserved and which must be transformed. Incidents like this are not new in plains Bali, but have occurred since the 1920s, for example between the Bali Adnyana and Surya Kanta groups. The first is conservative, i.e. wants to maintain traditional procedures, the old rules in society, while the second is aggressive in wanting to make changes in managing traditions when welcoming a new era.

According to Bourdieu, society as a social field and society as several social spheres such as religion, law, economy, politics, each of which has a relatively autonomous logik (Sutrisno et al., 2019). In the field, there are actors who have capital, be it social capital (social relations), economic capital (wealth), cultural capital (knowledge), and symbolic capital (degrees, prestige). Capital is defined as a resource or quality owned by an individual or social position that has social influence or value. The actors who own the capital want to get a recognition, so that the collection/hoarding/accumulation of symbolic capital ownership intends to determine who is in the dominating position and who is in the dominated position. The goal is to gain recognition that the influential self or group has 
the authority to determine the truth that is most widely followed (Fausi Fahri, 2007: 10). Thus, for the treatment of one party who intends to dominate the other party, a resistance is held which of course will have an impact and meaning.

And it turns out that compared to the content of quotations of other Hindu scriptures such as Sarasamuccaya, Menawa Dharmasastra, Yajur Weda Holy Scriptures there is an equation that, there is no mention of the term KASTA. Similarly, each varna does not occur because the lineage, let alone passed down through generations. Society is grouped into four groups according to talent, nature, and deed/work. Or in other words, people are classified according to their profession.

\section{Conclusion}

The results showed that the blurring of the varna system into a kasta concept is inseparable from the royal politics of its time. The traditional educational system originating from Hindu literature and religion can only be enjoyed by the upper layers, the brahmins and the knights, while the sudra or jaba classes are strictly prohibited. The kasta architects of Bali in the past few centuries, so expertly exploit the situation of the backwardness of Hindus outside the brahmana and the ksatria, so the teachings of Hinduism are manipulated in terms of kasta naming. The elements of caste plagiarize the elements of varna that are indeed Hindu teachings. In addition, Dutch colonial politics is also very influential on the order of life in Bali, which causes problems in the system of social status. The Belanda government has not fully implemented the modern system of government. This is evident in the system of appointment of new employees (civil servants). The Belanda government has not carried out according to rational legal criteria, but still uses the traditional system of judging a person in terms of the height of the kasta, not in terms of ability.

In the context of problems like this, deconstructive thinking strategies need to be applied to interpret the hidden meanings of terms which sometimes tend to be privileged through history. In order to appear a sense of justice, it is necessary to pay attention to or consider the elements of sekala and niskala.

\section{References}

Agung, A.A.G.P. (1974). Perubahan Sosial dan Pertentangan Kasta di Bali Utara 19241928. Thesis. Yogyakarta: Universitas Gajah Mada.

Bagus. (1991). Pemetaan Ulang Konstelasi Sosio Kultural Masyarakat Hindu Indonesia dalam: Kontek Transformasi Agama Hindu Masa Depan Dan Tanggung Jawab Kita, DPP Bali Peradah Indonesia, Denpasar.

Bagus Takwin. (t.t.) Kata Pengantar. Proyek Intelektual Pierre Bourdieu : Melacak AsalUsul Masyarakat, Melampaui Oposisi Biner dalam Ilmu Sosial. dalam Richard Harker, Cheelen Mahar, Chris Wilkes (ed).,(Habitus x Modal + Ranah = Praktik). Pengantar Paling Komprehensif kepada Pemikiran Pierre Bourdieu. Yogyakarta: Jalasutra.

Barker. C. (2004). Culture Studies: Teori \& Praktik (Nurhati: Penerjemah). Yogyakarta: Kreasi Wacana.

Darma, P.I.N. (2004). Bali Menuju Jagaditha: Sebuah Pengantar dalam I Nyoman Darma Putra ed, Bali Menuju Jagaditha: Aneka Perspektif. Denpasar: Pustaka Bali Post. Hlm X-xii.

Darsana, I M., \& Holilulloh, H.Y. (2015). Persepsi Masyarakat Bali Terhadap Sistem Kasta di Desa Buyut Baru. Jurnal FIKIP Unila. 3(8). 1-15. http://jurnal.fkip.unila.ac.id/index.php/JKD/article/view/9997.

Eriyanto. (2001). Analisis Wacana, Pengantar Analisis Teks Media. Yogyakarta: LKIS 
Fausi Fashri. (2007). Penyingkapan Kuasa Simbol. Yogyakarta: Juxtapose.

Kerepun. M.K. (2004). Benang Kusut Nama Gelar di Bali. Denpasar: Bali Media Adikarsa.

Kertih, W., \& Susila, A.J. (2014). Kasta: Modalitas Sosial Yang Membanggakan dan Menghancurkan. Seminar Nasional Riset Inovatif II. Seminar Nasional Riset Inovatif II. 624-634.

Kuta Ratna. (2005). Sastra dan Cultural Studies Refresentasi Fiksi dan Fakta. Denpasar: Pustaka Pelajar.

Mantra, I.B. (1967). Bhagavadgita, Alih Bahasa dan Penjelasan. Jilid I dan II, Parisada Hindu Dharma.

Santika, I. G. N. (2020). Menelisik Akar Kegaduhan Bangsa Indonesia Pasca Disetujuinya Hasil Revisi UU KPK Dalam Perspektif Pancasila. Jurnal Ilmiah Ilmu Sosial, 6(1), 26-36. https://doi.org/10.23887/jiis.v6i1.25001

Santika, I. G. N. (2021). Pendidikan Kewarganegaraan (Studi Komparatif Konstitusi Dengan UUD 1945). Lakeisha.

Santika, I. G. N., Kartika, I. M., Ayu, I. G., \& Darwati, M. (2021). Reviewing The Handling Of Covid-19 In Indonesia In The Perspective Of The Pancasila Element Theory ( TEP ). Jurnal Etika Demokrasi (JED), 6(2), 40-51. https://doi.org/https://doi.org/10.26618/jed.v6i2.5272

Santika, I. G. N., Sujana, G., \& Winaya, M. A. (2019). Membangun Kesadaran Integratif Bangsa Indonesia Melalui Refleksi Perjalanan Historis Pancasila Dalam Perspektif Konflik Ideologis. Journal of Etika Demokrasi (JED), 4(2), 89-98. https://doi.org/https://doi.org/10.26618/jed.v4i2.2391

Sutrisno, N., Nyoman, N., Nikki, A., Sutarya, I. G., Duija, I. N., Surpi, N. K., Donder, I. K., Suwantana, I. G., Bagus, I., Surya, B., Pramana, A., Santika, I. G. N., \& Segara, I. N. Y. (2019). POLITIK HINDU. IHDN PRESS.

Swarniti, N. W. (2019). The Translation Procedures of Bible Translation. RETORIKA: Jurnal Ilmu Bahasa, 5(2), 187-196. https://doi.org/10.22225/jr.5.2.1277.187-196

Swarniti, N. W. (2021a). A Corpus Based Approach to the Analysis of Structures in Prepositional Phrase. Yavana Bhasha: Journal of English Language Education, 4(1), 18-22.

Swarniti, N. W. (2021b). Translation Methods Found in New Testament Bible of Mark ' s Gospel. RETORIKA: Jurnal Ilmu Bahasa, 7(2), 172-179. https://doi.org/https://doi.org/10.22225/jr.7.2.3823.172-179

Swarniti, N. W. (2021c). The Analysis of Semantics Meaning Found In Comments of Instagram Account of Info Denpasar. Prosiding Seminar Nasional Linguistik Dan Sastra (SEMNALISA), 193-199.

Wiana \& Raka Santri. (1993). Kasta dalam Hindu Kesalahpahaman Berabad-abad. Denpasar: Yayasan Dharma Narada 